\title{
SISTEM INFORMASI GEOGRAFIS JUKUNG PEDAGANG PASAR TERAPUNG KUIN KOTA BANJARMASIN
}

\author{
Dewi Nur Indah Sari' ${ }^{1)}$, Ferry Sobatnu' ${ }^{2)}$, Nurul Inayah ${ }^{3)}$ \\ 1,2,3) Politeknik Negeri Banjarmasin \\ e-mail: dewi.sari@poliban.ac.id ${ }^{1)}$, sobatnu@poliban.ac.id ${ }^{2}$, inayah_nurul@poliban.ac.id ${ }^{3)}$
}

\begin{abstract}
Banjarmasin is the capital city of South Kalimantan Province known as the city of a thousand rivers. The city is named Banjarmasin because of its geographical condition surrounded by large and small rivers. One of the community activities on the river is buying and selling in Floating Market. The Floating Market does not have an organization like in the land market, so it is not recorded how many traders or traders based on their goods. The goal is to create a Geographic Information System of Jukung Traders in Kuin Floating Market. This study used waterfall description model. The results of this study are displaying merchant support data through the Jukung Route Map of Kuin Floating Market and visualizing the database in the form of Visual Basic 6.0. The information displayed includes merchant data, jukung technical data, jukung operational data, house coordi-nate data and road routes that are occupied by each of the customers of Kuin Floating Market traders.
\end{abstract}

Keywords: Floating Market, GIS, DataBase, Map and Visual Basic 6.0.

\section{ABSTRAK}

Banjarmasin merupakan ibukota Provinsi Kalimantan Selatan yang dikenal sebagai kota seribu sungai. Kota ini bernama Banjarmasin karena kondisi geografisnya yang dikelilingi oleh sungai besar dan kecil. Salah satu aktivitas masyarakat di atas sungai adalah jual beli di Pasar Terapung. Pasar Terapung tidak memiliki organisasi seperti pada pasar didaratan, sehingga tidak tercatat berapa jumlah pedagang atau pembagian pedagang berdasarkan barang dagangannya. Tujuan dari penelitian ini yaitu membuat Sistem Informasi Geografis Jukung Pedagang di Pasar Terapung Kuin. Penelitian ini menggunakan model sekuensial linier. Data dikumpulkan melalui proses wawancara dan observasi. Hasil penelitian ini yaitu menampilkan data jukung pedagang melalui Peta Rute Jukung Pasar Terapung Kuin dan memvisualisasikan database dalam bentuk tampilan Visual Basic 6.0. Informasi yang ditampilkan antara lain yaitu data pedagang, data teknik jukung, data operasional jukung, data koordinat rumah dan rute perjalanan yang ditempung masing-masing jukung pedagang Pasar Terapung Kuin. Kata Kunc: Pasar Terapung, , SIG, DataBase, Peta dan Visual Basic 6.0..

\section{PENDAHULUAN}

$\mathrm{B}$ ANJARMASIN merupakan Ibukota Provinsi Kalimantan Selatan yang memiliki banyak sungai sebagai salah satu sumber daya alamnya. Sungai terbesar dan terpanjang di Kalimantan Selatan adalah Sungai Barito, yang mata airnya berasal dari pedalaman Kalimantan Tengah dan bermuara ke Laut Jawa. Sungai Barito mempunyai banyak anak sungai sepanjang aliran sungai ini khususnya di Ko-ta Banjarmasin, sejak zaman dulu telah menjadi tempat konsentrasi penduduk. Oleh karena itu, sejak dulu banyak pemukiman dan aktivitas serta transportasi air oleh masyarakat disekitaran muara sungai atau tepi sungai [1].

Salah satu aktivitas masyarakat di atas sungai adalah jual beli di Pasar Terapung yang merupakan pasar tradisional yang berada diatas sungai khususnya di Kota Banjarmasin, Kalimantan Selatan. Pasar yang dinamakan Pasar Terapung atau Pasar Apung ini hanya terdapat di daerah Kalimantan Selatan khususnya Banjarmasin. Pasar ini menjadi obyek wisata yang menarik untuk dikunjungi sekaligus sebagai media perputaran uang di daerah tersebut. Kini tidak saja sebagai pusat perdagangan bagi masyarakat lokal, tetapi juga sudah menjadi obyek wisata yang dapat menunjang para wisatawan untuk menggerakkan sektor ekonomi di kawasan tersebut. Pasar terapung Muara Kuin merupakan salah satu obyek wisata unggulan Kalimantan Selatan yang harus tetap dijaga kelestariannya [2].

Penggunaan Sistem Informasi Geografis (SIG) sangat diperlukan dalam pemanfaatan rute 
operasional jukung di Kota Banjarmasin. Sistem informasi Geografis (SIG) merupakan sistem informasi berbasis komputer yang digunakan untuk mengolah dan menyimpan data atau informasi geografis. SIG mempunyai kemampuan untuk menghubungkan berbagai data pada suatu titik tertentu di bumi, menggabungkannya, menganalisa dan akhirnya memetakan hasilnya. Hal ini dikarenakan SIG mampu membantu dalam hal mengatur data dari berbagai masalah untuk memahami dari sisi spasialnya. SIG dapat digunakan untuk aplikasi-aplikasi pada pemerintahan daerah yaitu, sebagai salah satu alat bantu perencanaan daerah dan tata ruang yang diperuntukkan lahan untuk calon investor, informasi potensi, untuk pemetaan dan pengelolaan sumber daya alam.

Oleh karena permasalahan di atas, peneliti tertarik untuk membuat sebuah sistem informasi dengan menyusun basis data tentang jukung yang berlokasi di Pasar Terapung Kuin. Hal ini sesuai dengan tujuan dari sistem basis data yaitu menghubungkan data satu dengan yang lainnya yang diorganisasikan berdasarkan sebuah skema atau struktur tertentu, tersimpan dihardware komputer dan dengan software untuk melakukan manipulasi untuk kegunaan tertentu. Selain itu, manfaat lain yang dapat diperoleh dari penelitian ini yaitu memberikan alternatif instrumen kepada Dinas Pariwisata dalam pengelolaan objek wisata tradisional agar dapat dilestarikan dan dikembangkan serta memberikan informasi bagi pemerintah agar dapat menggali potensi pedagang di Pasar Terapung Kuin untuk meningkatkan sektor ekonomi.

\section{STUDi LiTERATUR}

Penelitian mengenai pembuatan sistem informasi sudah sering dilakukan di berbagai daerah. Pada penelitian ini disusun sistem informasi pengelolaan jukung Pedagang Pasar Terapung Kuin Kota Banjarmasin. Pasar yang dinamakan Pasar Terapung atau Pasar Apung ini hanya terdapat di daerah Kalimantan Selatan khususnya Banjarmasin. Pasar ini menjadi obyek wisata yang menarik untuk dikunjungi sekaligus sebagai media perputaran uang di daerah tersebut. Kini tidak saja sebagai pusat perdagangan bagi masyarakat lokal, tetapi juga sudah menjadi obyek wisata yang dapat menunjang para wisatawan untuk menggerakkan sektor ekonomi di kawasan tersebut. Pasar terapung Muara Kuin merupakan salah satu obyek wisata unggulan Kalimantan Selatan yang harus tetap dijaga kelestariannya [2].

Terdapat beberapa penelitian yang digunakan sebagai referensi dalam penyusunan penelitian ini. Fahrudin melakukan penelitian tentang bagaimana cara atau proses kerja program sehingga dapat menghasilkan program basis data siswa, data guru dan data karyawan di SMP Negeri 4 Kudus dengan menggunakan Microsoft Visual Basic 6.0 dan Crystal Report. Metode penelitian yang dilakukan dalam kegiatan ini adalah merancang dan membuat program database sistem informasi di SMP N 4 Kudus [3].

Pada tahun 2013 Lestari melakukan penelitian tentang pembuatan sistem informasi geografis berbasis Web untuk pemetaan pariwisata Kabupaten Kebumen. Metode yang dilakukan dalam penelitian ini menggunakan beberapa tahapan yaitu mulai dari perencanaan sistem, analisis, rancangan, penulisan program sampai dengan tahap implementasi dan pengujian. Tahapan perencanaan bertujuan untuk mencari solusi-solusi dari permasalahan tentang pemetaan pariwisata di kabupaten Kebumen. Tahapan analisis dilakukan untuk menyelesaikan permasalahan yang timbul dengan diagram alir. Tahapan selanjutannya yaitu perancangan user interface dan rancangan pencarian rute terpendek. Tahapan yang terakhir yaitu implementasi dan pengujian melalui uji coba sistem mengenai kemampuan sistem yang diharapkan dan yang dihasilkan [4].

Selain dari beberapa penelitian di atas pada tahun 2011 Rochgiyanti melakukan penelitian tentang fungsi sungai bagi masyarakat di tepian Sungai Kuin Kota Banjarmasin. Dalam penelitiannya rochgiyanti menjelaskan tentang fungsi sungai, khususnya bagi masyarakat di tepian Sungai Kuin di Kota Banjarmasin. Peneliti ingin mengetahui apakah sungai masih mempunyai fungsi bagi masyarakat di Kuin, meskipun pembangunan jalan darat yang lebih modern telah dilakukan. Sehingga didapatkan bahwa Sungai bagi masyarakat di Tepian Sungai Kuin masih memegang peranan yang cukup penting dalam berbagai segi kehidupan. Sungai tidak hanya semata-mata berfungsi sebagai jalur transportasi, tetapi sungai juga berperan dalam aktivitas perekonomian. Selain itu masih banyak warga masyarakat yang memanfaatkan sungai untuk keperluan mandi dan cuci. Sambil melakukan aktivitas tersebut, warga masyarakat bisa melakukan interaksi untuk berbagai tujuan. Selain sebagai media interaksi, 
tepian sungai juga dijadikan sebagai sarana sosialisasi untuk belajar kebudayaan masyarakatnya.

\section{A. Basis Data}

Sistem basis data adalah sistem komputerisasi yang tujuan utamanya adalah memelihara informasi dan membuat informasi tersebut tersedia saat dibutuhkan [5]. Pengguna basis data bisa melakukan berbagai operasi, antara lain sebagai berikut.

1. Menambahkan file baru ke sistem basis data

2. Mengosongkan berkas

3. Menyisipkan data ke suatu berkas

4. Mengambil data yang ada pada suatu berkas

5. Mengubah data pada suatu berkas

6. Menghapus data pada suatu berkas

7. Menyajikan suatu informasi yang diambil dari sejumlah berkas [3]

\section{B. Sistem Informasi}

Sistem informasi dapat didefinisikan sebagai suatu sistem di dalam suatu organisasi yang merupakan kombinasi dari orang-orang, fasilitas, teknologi, media, prosedur-prosedur dan pengendalian yang ditujukan untuk mendapatkan jalur komunikasi penting, memproses tipe transaksi rutin tertentu, memberi sinyal kepada manajemen dan yang lainnya terhadap kejadian-kejadian internal dan eksternal yang penting dan menyediakan suatu dasar informasi untuk pengambilan keputusan yang cerdik [6].

\section{Sejarah Jukung Banjar}

Sungai Kuin Utara merupakan salah satu sungai besar di Kota Banjarmasin yang memiliki lebar 40 meter dengan permukiman tepi sungainya yang merupakan ciri khas dari kebudayaan sungai. Secara administrasi, permukiman di tepian Sungai Kuin Utara termasuk dalam wilayah Kelurahan Kuin Utara atau yang lebih dikenal dengan Kawasan Kampung Kuin. Kawasan inilah yang menjadi cikal bakal Kota Banjarmasin yang diawali oleh adanya kehidupan dan kegiatan yang berorientasi pada sungai, dengan pusat pemerintahan Kerajaan Banjar yang terdapat pada tepian Sungai Kuin, sehingga Kawasan Kuin merupakan cikal bakal dari Kota Banjarmasin [7].

Pasar terapung merupakan salah satu tradisi dan kearifan local masyarakat Banjar saat ini sedikit demi sedikit tergerus oleh perubahan social baik secara structural maupun fungsional. Perubahan pada satu aspek dalam masyarakat akan berpengaruh pada aspek lainnya. Perubahan social sebagai konsekuensi dari aktivitas manusia, inovasi, kemajuan sains dan teknologi [8].

Keberadaan Pasar Terapung di muara Kuin memang tumbuh bers amaan dengan adanya komunekomune yang secara tetap mendiami daerah sekitarnya. Di areal muara Sungai Kuin dan sekitarnya terdapat lima kelompok suku bangsa yang hidup berdampinga $\mathrm{n}$ secara damai. Keberadaan masyarakat dan kontak antar kelompok yang mendiami lokasi yang menjadi cikal bakal kota Keraja an Banjar inilah yang melahirkan pasar di muara Sungai Kuin, yang sekarang dikenal sebagai Pasar Terapung. Pasar di muara Sungai Kuin bertambah semakin hidup dan ramai ketika lahir Kerajaan Banjar dengan ditetapkannya Pangeran Samudera sebagai raja oleh para patih yang dipelopori oleh patih Masih pada tahun 1595. Ketika pemerintah menetapkan sektor pariwisata sebagai aset untuk meningkatkan devisa negara, maka sejak tahun 1980an Pasar Terapung ikut mendapat perhatian untuk dijual kepada wisata wan baik domestik maupun wisatawan mancanegara. Pasar Terapung kemudian menjadi terkenal. Inilah sejarah singkat dari Pasar Terapung, yaitu keunikan pasar yang dimiliki Kalimantan Selatan, Banjarmasin [9].

Jukung Tradisional merupakan produk budaya Banjar manusia sejak masa prsasejarah ketika manusia baru menemukan moda transportasi air menjelang berakhirnya kala Neolitik, sesudah penggunaan rakit-rakit bambu. Dalam studi sejarah dan arkeologi peninggalan-peninggalan jukung atau perahu sebagai artefak benda bergerak dapat mengungkapkan peristiwa-peristiwa sosial, ekonomi, budaya dan politik dimasa lampau dalam lingkungan geografis etnik pendukungnya ataupun dalam lingkungan yang lebih luas yang berkaitan dengan fakta migrasi di masa lampau.

Berdasarkan kenyataan arkeologis dan historis, jukung-jukung orang Banjar masih banyak terdapat dan digunakan di perairan Kalimantan Selatan. Bahkan pasar terapung (floating markets) di daerah ini, 
diketahui sudah ada sejak 400 tahun yang lalu. Diperkirakan pasar terapung dan juga di tebing sungai sudah ada pada tahun 1530 Masehi pada masa pemerintahan Sultan Suriansyah (Pangeran Samudera) yang terletak pada pertemuan Sungai Karamat dan Sungai Sigaling. Kemudian bergeser ke tepi sungai Barito di daerah muara Sungai Kuin menjelang akhir abad ke-16 atau awal abad ke-17 Masehi. Pasar terapung di sungai Desa Lok Baintan, Kabupaten Banjar, mungkin sudah ada pada abad ke-16 tetapi bisa juga baru menjadi umum ketika perpindahan keraton Banjar ke kawasan Kayu Tangi Martapura sejak awal abad ke-17 (1612). Disamping karena tipe-tipe jukung tradisionalnya dan keberadaan pasar terapung tersebut bernilai sejarah dan arkeologi, maka sepantasnya bisa diusulkan sebagai budaya unggulan masyarakat Banjar sebagai lokasi pariwisata berbasis arkeologi. Masyarakatnya tentunya juga sangat memerlukan bantuan pembinaan dari pemerintah dan pihak-pihak terkait lainnya sebagai kegiatan peningkatan ekonomi kreatif kalangan masyarakat bawah [10].

\section{METODE PENELITIAN}

\section{A. Lokasi Penelitian}

Penelitian ini berada di Kota Banjarmasin Kecamatan Banjarmasin Utara Provinsi Kalimantan Selatan tepatnya di Pasar Terapung Kuin.

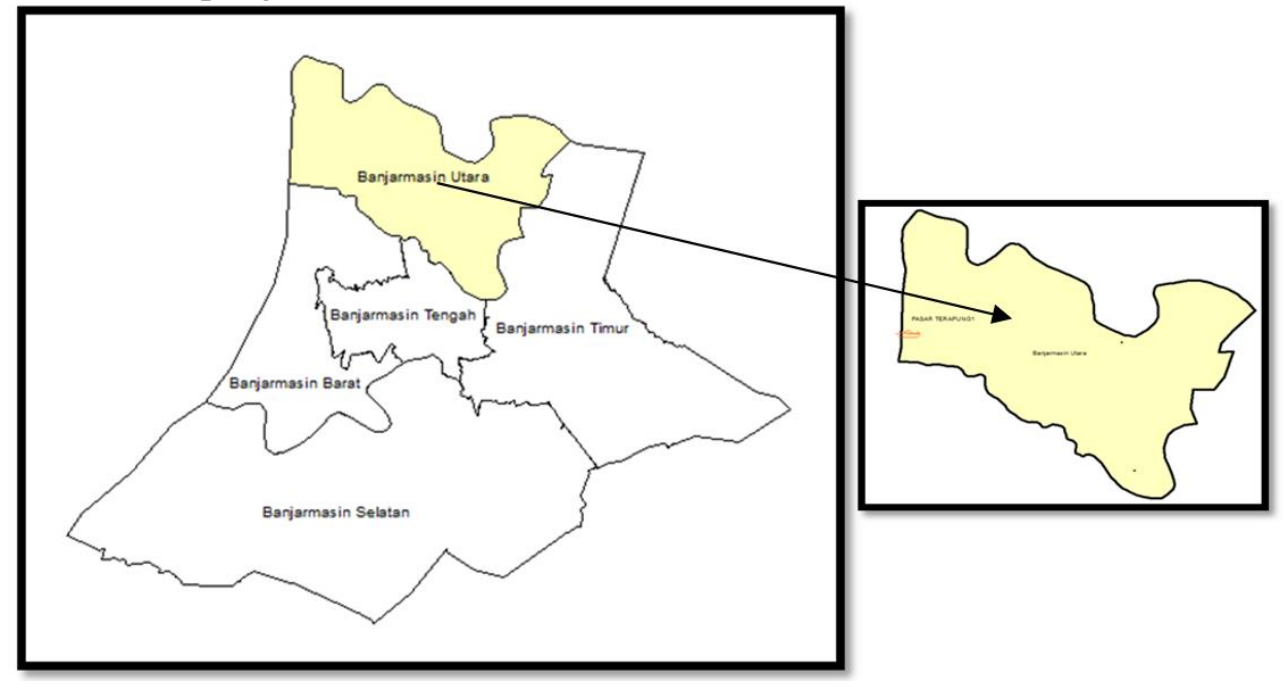

Gambar 1. Letak Lokasi Penelitian

\section{B. Metode}

Berdasarkan latar belakang yang telah disusun di atas, metode yang diterapkan dalam penelitian ini yaitu sebagai berikut.

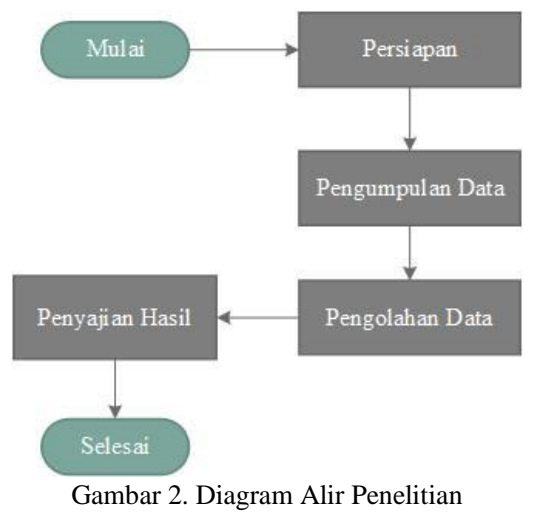

Berikut penjelasan dari diagram alir metode penelitian.

1. Persiapan

a. Identifikasi Masalah

Permasalahan dalam penelitian ini adalah pembuatan sistem informasi geografis pedagang jukung pasar terpaung kuin dengan memanfaatkan aplikasi ArcGIS dan Visual Basic 6.0. 
b. Studi Literatur

Bertujuan untuk mendapatkan referensi yang berhubungan dengan pengelolaan data jukung, sistem basis data, Sistem Informasi Geografis dan literatur lain yang mendukung baik dari buku, jurnal, majalah, koran, internet dan lain-lain.

2. Pengumpulan Data

Pengumpulan data dilakukan dengan dua cara yaitu: primer dan sekunder yang meliputi data spasial dan nonspasial. Adapun data spasial yang dibutuhkan diantaranya data batas administrasi dan data koordinat rumah pedagang. Sedangkan data nonspasial yang dibutuhkan antara lain data pedagang, teknik jukung dan operasional jukung.

3. Pengolahan Data

Pada tahapan ini dilakukan pengolahan data spasial dan nonspasial menjadi sebuaha basis data jukung pasar terapung dengan memanfaatkan model sekuensial linier meliputi proses rekayasa dan pemodelan sistem informasi, analisis kebutuhan perangkat lunak, desain, pengujian, dan pemeliharaan. Sehingga dihasilkan Sistem Informasi Geografis pedagang jukung pasar terapung kuin.

4. Penyajian Hasil

Penyajian hasil dilakukan untuk mendapatkan Peta Rute Operasional Jukung Pedagang Pasar Kuin Kota Banjarmasin. Selain itu hasil yang lain yaitu tampilan database jukung pedagang menggunakan aplikasi Visual Basic 6.0.

\section{HASIL DAN PEMBAHASAN}

Data yang didapatkan berdasarkan titik sampel $n=25 \%$ x120 ada 30 sampel data jukung pedagang pasar terapung kuin untuk mengambil Titik lokasinya. Berdasarkan data yang telah diambil ada 30 kode jukung diantaranya yaitu $(002,007,011,015,017,021,022,028,029,037,038,040,042,048,049$, 051,053, 054, 055, 056, 058, 059, 061, 062, 063, 065, 066, 067, 070, 072).

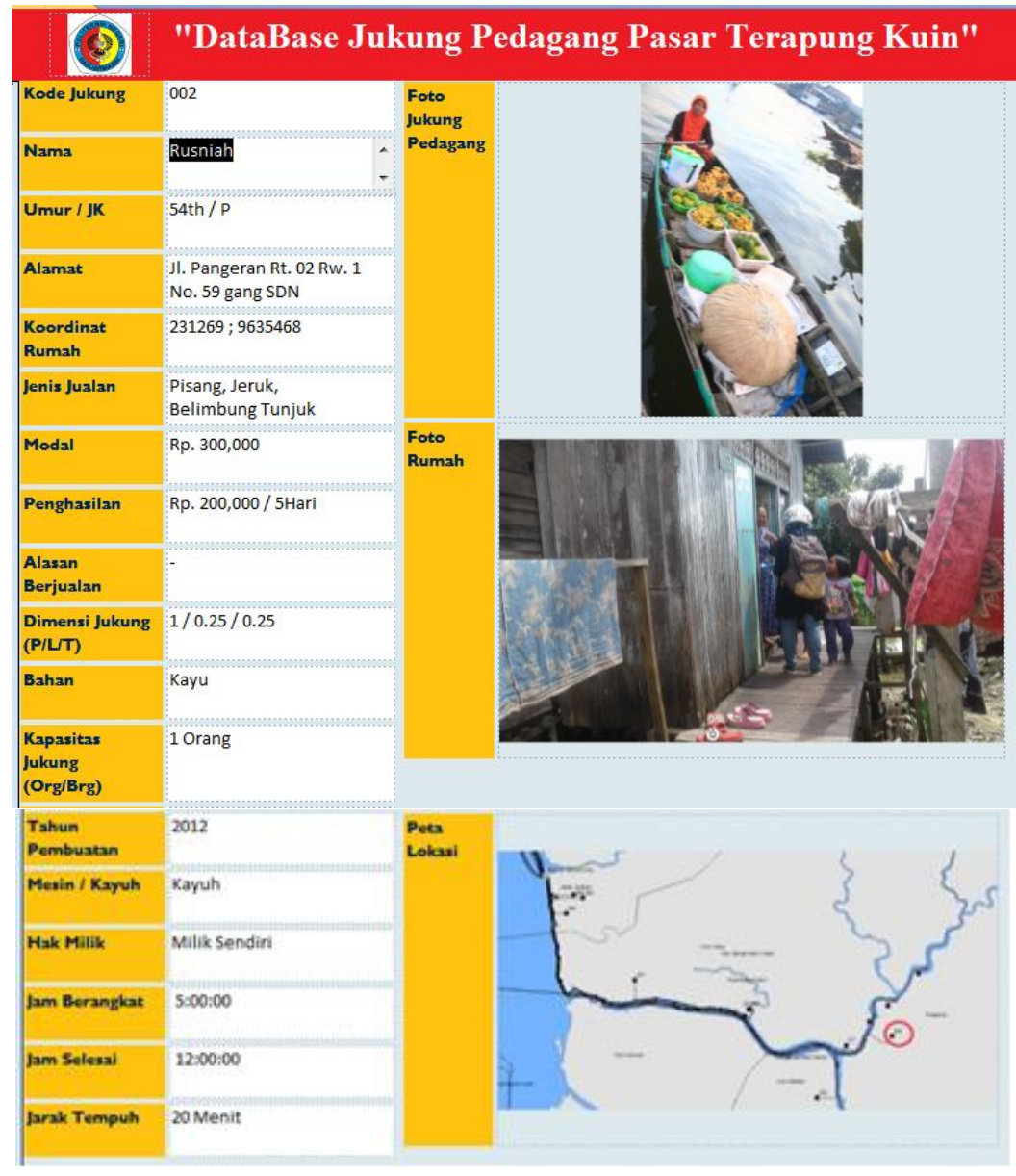

Gambar 3. Database Jukung Pedagang Pasar Terapung Kuin 
Titik Lokasinya tersebar di Kelurahan Pangeran, Kuin Utara, Alalak Selatan, Alalak Tengah, Alalak Utara, Pulau Alalak, Pulau Sewangi, Pulau Sugara, Berangas Timur, Tatah Masjid, Kuin Selatan, dan Sungai Miai. Dengan jarak tempuh kebanyakan dalam 30 Menit sampai 1 jam, adapun dengan cara bergandeng.

Pada Database Jukung Pedagang Pasar Terapung Kuin, disusun pada Microsoft Acesss 2007. Hasil survey yang didapatkan dibuat dalam bentuk database seperti pada Gambar 3. Foto pertama diambil pada saat pedagang berjualan di Pasar Terapung Kuin, foto kedua diambil pada saat pengambilan Titik Koordinat dirumah pedagang, foto ketiga adalah lokasi rumah pedagang yang berjualan di Pasar Terapung Kuin.

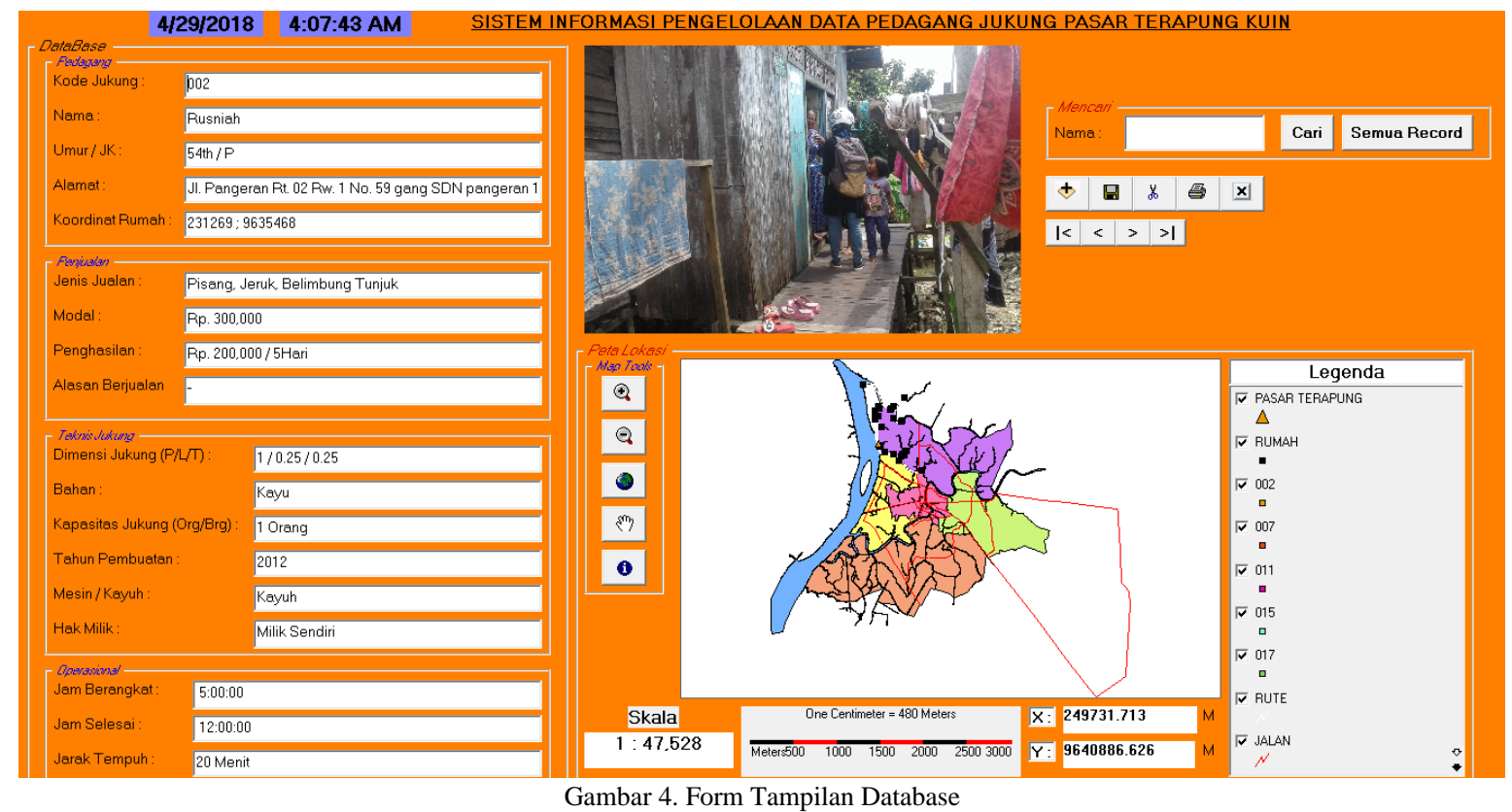

Pada Gambar di atas, komponen yang dibuat adalah Label, TextBoxt, CammondButton, Image, Data Grid, Adodcl. Pada Adodcl yang sumber data yang dihubungkan adalah dari Database Access, pada DataGrid sumber datanya adalah dari Adodc1, kemudian pada textbox1 samping label Kode Jukung pilih DataSource nya Adodc1 lalu pada DataField Kode Jukung, kemudian pada textbox2 samping label Nama pilih DataSource Adodcl lalu pada DataField Nama. Lakukan terus dan sesuaikan database sampai pada Jarak Tempuh.

Untuk Tampilan Peta Lokasi, komponen yang dibuat adalah Map, Legend, ScaleBar yang dihubungkan dan disesuaikan dengan .shp pada ArcGIS.

Pada Gambar 5 ditampilkan contoh hasil cetak database dengan mengklik perintah cetak maka akan muncul tampilan Data report yang sudah didesain sesuai keinginan. Dengan begitu, maka database siap untuk dicetak.

Dari hasil pembahasan di atas didapatkan hasil Peta Rute Operasional Jukung Pedagang Pasar Terapung Kuin dan hasil tampilan database dalam aplikasi Visual Basic 6.0. Informasi yang ditampilkan berkaitan tentang data pedagang yaitu nama, alamat, jenis kelamin, dll. Informasi lain yang ditampilkan yaitu tentang teknis jukung meliputi bahan jukung, jenis dan tahun pembuatannya. Selain itu data operasional jukung juga ditampilkan dalam hasil database meliputi informasi jam berangkat, jam pulang dan jarak tempuh. Data spasial berupa data koordinat juga ditampilkan guna mengetahui lokasi geografis dari rumah pedagang Pasar Terapung Kuin Kota Banjarmasin.

Sampel data jukung yang digunakan dari penelitian ini berjumlah 30 sampel dengan lokasi yang menyebar di beberapa tempat, diantaranya di daerah Kuin sampai dengan daerah Sungai Miai. Dalam pengolahannya peneliti mendapat beberapa kendala yaitu pada saat survei lapangan, kendala yang dialami yaitu terbatasnya data alamat rumah pedagang Pasar Terapung. Hal ini menyebabkan proses pengambilan koordinat berlangsung lama sehingga tidak sesuai dengan jadwal kegiatan yang telah dibuat sebelumnya. Selain itu kendala lain yang dialami peneliti yaitu dalam pembuatan tampilan 
database di aplikasi Visual Basic 6.0. Permasalahan yang dialami peneliti yaitu ketika proses penggabungan file database dengan data peta yang memiliki format shp. Namun beberapa kendala di atas telah dapat diatasi dengan hasil berupa Sistem Informasi Pengelolaan Jukung beserta report hasil tampilannya.

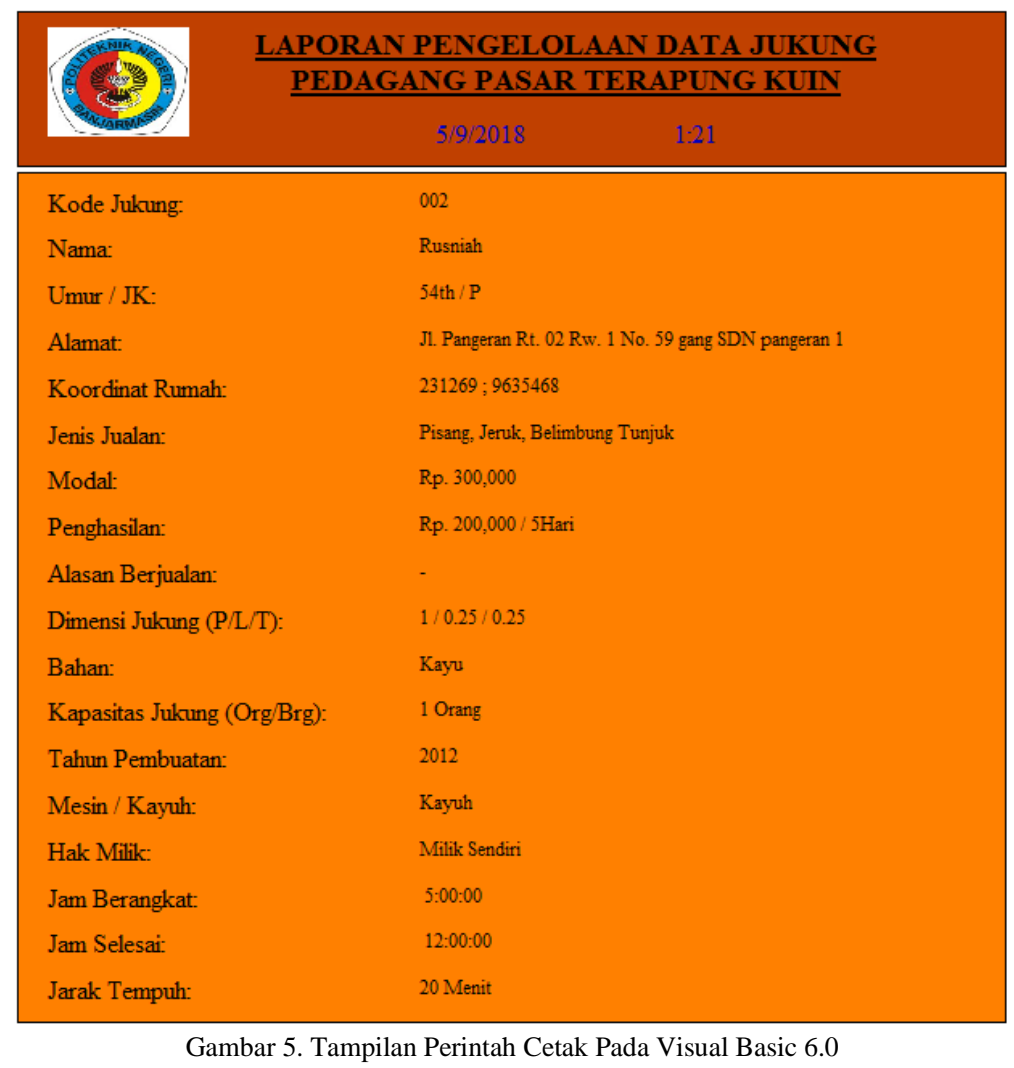

Pada penelitian ini, peneliti menentukan manfaat utama yaitu pembuatan sistem informasi pengelolaan jukung khususnya di Pasar Terapung Kuin Kota Banjarmasin. Sistem informasi ini diharapkan dapat dimanfaatkan oleh berbagai kalangan sesuai dengan tujuannya. Selain itu faktor untuk melestarikan budaya di Kota Banjarmasin sebagai Kota Seribu Sungai juga sangat diperhatikan oleh peneliti. Hal ini sesuai dengan yang ditulis Rochgiyanti dalam penelitiannya bahwa Sejak dulu sungai memegang peranan penting sebagai jalur transportasi di wilayah ini, sebab sungai-sungai yang melewati wilayah Kuin bermuara di Sungai Barito sebagai sungai terbesar di Kalimantan Selatan. Meskipun frekuensi transportasi sungai mulai berkurang, namun masih ada sebagian warga yang menggunakan jalur sungai. Setiap pagi bisa diamati transportasi tradisional sungai, seperti jukung dan klotok (taksi klotok) yang hilir mudik di sungai. Menurut Petersen, jukung adalah istilah yang digunakan oleh seluruh masyarakat dataran rendah Barito dan digunakan untuk semua jenis perahu/badan kapal.

\section{KESIMPULAN}

Berdasarkan pembahasan hasil di atas didapatkan data 30 jukung pedagang Pasar Terapung Kuin yang beroperasi setiap harinya. Selain itu, informasi lain yang dapat ditampilkan dalam database ini yaitu meliputi data pedagang (nama, alamat pedagang,dll), data teknik jukung (bahan, tahun pembuatan, dll), data operasional jukung (jam berangkat, jam pulang, jarak tempuh). Selain itu data spasial yang ditampilkan dalam penelitian ini yaitu data koordinat dan rute operasional jukung. Database tersebut ditampilkan dalam bentuk Peta Rute Jukung Pasar Terapung Kuin dan divisualisasikan dalam database menggunakan aplikasi Visual Basic 6.0.

\section{DAFTAR PUSTAKA}

[1] Rochgiyanti, "Fungsi Sungai Bagi Masyarakat di Tepian Sungai Kuin Kota Banjarmasin,” J. Komunitas, vol. 3, no. 1, pp. 51-59, 2011.

[2] Akhbianor; E. Normely; dan P. Anggraeni, “1. Mahasiswa Program Studi Pendidikan Geografi FKIP Universitas Lambung Mangkurat 2. Dosen Program Studi Pendidikan Geografi FKIP Universitas Lambung Mangkurat 26,” J. Pendidik. Geogr., vol. 2, no. 6, pp. 26-39, 
2015.

[3] “Aplikasi Microsoft Visual Basic 6.0 Dalam Pembuatan Sistem Informasi Di Smp Negeri 4 Kudus Tahun 2008,” 2008.

[4] P. Lestari et al., "Sistem Informasi Geografis Berbasis Web Untuk Pemetaan Pariwisata Kabupaten Kebumen," Teknol. Inf. dan Ilmu Komput., vol. 11, no. 1, pp. 45-57, 2013.

[5] Kadir 2014:218, "Pengenalan Sistem Informasi," Am. Enterp. Inst. Public Policy Res., no. August, pp. 1-19, 2014.

[6] Fakultas Keguruan dan Ilmu Pendidikan, "Sungai dan kehidupan masyarakat banjarmasin," 2012.

[7] R. Rahmitiasari et al., "Perubahan Arah Hadap Bangunan Pada Permukiman Tradisional," January 2014.

[8] Sakdiah,"Peran Pedagang Perempuan Pasar Terapung Dalam Melestarikan Tradisi Dan Kearifan Lokal Di Kalimantan Selatan," IAIN Antasari Banjarmasin, 2016.

[9] H. M. Hanafiah, "Masyarakat Banjar," Al-Tahrir, vol. 15, no. 1, pp. 201-217, 2015.

[10] Ridhoni, "Jukung Dalam Persepktif Nilai Sosial Masyarakat Banjar Di Desa Pulau Sewangi," Development, vol. 134, no. 4, pp. 635$646,2007$. 